\title{
Barriers to implementing a health policy curriculum in medical schools
}

This article was published in the following Dove Press journal:

Advances in Medical Education and Practice

\section{Raihan Mohammed Jamil Shah Foridi Innocent Ogunmwonyi \\ Faculty of Medicine, University of Cambridge, Cambridge, UK}

Correspondence: Raihan Mohammed Robinson College, University of Cambridge, Cambridge CB3 9AN, UK Tel +44787 I736004 Email rm758@cam.ac.uk

\section{Dear editor}

As clinical medical students, we read with great interest the perspective by Malik et al. ${ }^{1}$ Although medical schools excel at educating students on the pathology and treatment of diseases, we agree on the severe deficiency in teaching health policy (HP) in the medical curriculum. However, the authors fail to include challenges facing this implementation, which is an important aspect of the analysis. Thus, here we outline 3 key barriers that must be considered when including HP teaching in the medical curricula.

First, as the authors mention, the medical curriculum is already saturated and there is insufficient space to add obligatory HP learning in timetables. The UK curriculum is so packed that lecturers resort to teaching facts, which students then rote-learn and commit to memory. This leaves little time for students to develop a deep understanding of the pathophysiology of diseases and subsequent management, and they also fail to develop core lifelong skills, including problem solving and critical thinking. ${ }^{2}$ It is well acknowledged that the medical course is extremely rigorous, and up to $90 \%$ of students have admitted to suffering from stress and up to $75 \%$ have complained of burnout. ${ }^{3}$ With mental health issues among students reaching epidemic levels, adding HP lectures to the timetable would put undue strain on both the medical school curricula and the students.

Second, implementing an HP course would require a multidisciplinary faculty team, which includes epidemiologists, health economists, and sociologists among others. This team would need to be integrated with the medical faculty; however, there is already a physical segregation of schools of public health from medical departments, which has institutionalized a degree of separation. This independence has caused population-based health care to mean little to most undergraduate students and many consider public health a postgraduate endeavor. ${ }^{4}$ In addition, many medical schools do not employ academics for medical education in fields of social sciences, management and economics, and current lecturers (often clinicians) are generally untrained in these areas. Thus, targeted recruitment would be required in a time of health care reforms and staff shortages to meet this demand.

Finally, as many institutions fail to include any HP teaching, there is very little precedence as to how an HP curriculum should be taught. One relevant example is the current effort to introduce leadership and management (LM) teaching to core medical curricula. With little research evaluating methods of implementing LM teaching, institutions had poor results, with no robust evidence to show that their approach of adding in lectures improved leadership development. ${ }^{5}$ There must be greater effort 
and funding to research how to effectively incorporate an HP course into the current medical curriculum before implementing it nationwide. All medical schools should openly participate in pilot programs to provide feedback on different iterations of the course to eventually produce an efficient, standardized curriculum.

In conclusion, we support the implementation of an HP course within the current medical curriculum. However, there are several limitations, which must be addressed to develop this, including the course content and the practicalities of its incorporation in different institutions.

\section{Author contributions}

RM, JSF, and IO were involved in the conception, design, drafting, revision, and final approval of the letter.

\section{Disclosure}

The authors report no conflicts of interest in this communication.

\section{References}

1. Malik B, Ojha U, Khan H, Begum F, Khan H, Malik Q. Medical student involvement in health policy roles. Adv Med Educ Pract. 2017;8: 735-743.

2. Lujan HL, DiCarlo SE. Too much teaching, not enough learning: what is the solution? Adv Physiol Educ. 2006;30(1):17-22.

3. Fares J, Al Tabosh H, Saadeddin Z, El Mouhayyar C, Aridi H. Stress, burnout and coping strategies in preclinical medical students. $N \mathrm{Am} J$ Med Sci. 2016;8(2):75-81.

4. Woodward A. For Debate: public health has no place in undergraduate medical education. J Public Health. 1994;16(4):389-392.

5. Abbas MR, Quince TA, Wood DF, Benson JA. Attitudes of medical students to medical leadership and management: a systematic review to inform curriculum development. BMC Med Educ. 2011;11:93.

Dove Medical Press encourages responsible, free and frank academic debate. The content of the Advances in Medical Education and Practice 'letters to the editor' section does not necessarily represent the views of Dove Medical Press, its officers, agents, employees, related entities or the Advances in Medical Education and Practice editors. While all reasonable steps have been taken to confirm the content of each letter, Dove Medical Press accepts no liability in respect of the content of any letter, nor is it responsible for the content and accuracy of any letter to the editor.

\section{Publish your work in this journal}

Advances in Medical Education and Practice is an international, peerreviewed, open access journal that aims to present and publish research on Medical Education covering medical, dental, nursing and allied health care professional education. The journal covers undergraduate education, postgraduate training and continuing medical education including emerging trends and innovative models linking education, research, and health care services. The manuscript management system is completely online and includes a very quick and fair peer-review system. Visit http://www.dovepress.com/testimonials.php to read real quotes from published authors. 